\title{
Associated risk factors with pregnancy-induced hypertension: A hospital-based KAP study
}

Background: Hypertension, complicating $5-10 \%$ of all pregnancies, is a leading cause of maternal and fetal morbidity, particularly when the elevated blood pressure is due to preeclampsia. The control of pregnancy-induced hypertension (PIH) appears difficult to achieve. Part of the reason for poor control of hypertension in these women might be limited PIH self-care knowledge. Aims: The aim was to find out the association between $\mathrm{PIH}$ and knowledge, attitude, and preventive practices among pregnant women. Settings and Design: A cross-sectional study was carried out in Gynae O.P.D., of Sir Sundar Lal Hospital, Banaras Hindu University, Varanasi. Materials and Methods: The study was carried out in the month of September to October, 2013 on every Monday in Gynae O.P.D., of Sir Sundar Lal Hospital, Banaras Hindu University, Varanasi. The target population includes all pregnant women between the age group of 15-49 years, who attended antenatal clinic. The interview schedules were administered to the women. Respondents were assured of anonymity and confidentiality to ensure honest response. Statistical Analysis Used: Statistical analysis will be done by Epi Info"' 7. Results and Conclusion: Finding of the study shows that $>50 \%(60.49 \%)$ of women are unaware about hypertension. Those women belong to the age group of 20-30, and they also diagnosed with prehypertension. The overall incidence of Eclampsia is $13.58 \%$ in study population regarding $\mathrm{PIH}$. Lack of exercise is a major cause to for hypertension. Pregnancies complicated by hypertensive disorders lead poor maternal and perinatal outcomes.

Key words: Hypertension, preeclampsia, pregnancy-induced hypertension, risk

Vineeta Singh, Manushi Srivastava

Department of Community Medicine, Institute of Medical

Sciences, Banaras Hindu

University, Varanasi, Uttar Pradesh, India

Address for the Correspondence: Dr. Vineeta Singh,

(Research Scholar)

Department of Community Medicine, Institute of Medical

Sciences, Banaras Hindu University, Varanasi - 221 005,

Uttar Pradesh, India.

E-mail: vini.bhu2009@gmail.com

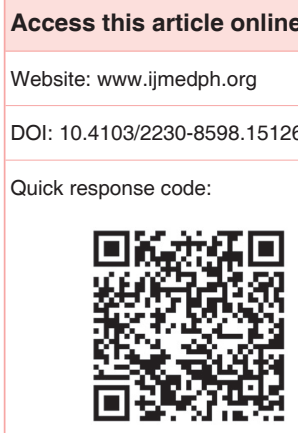

factors, self-care knowledge

\section{INTRODUCTION}

Pregnancy-induced hypertension (PIH) known as toxemia or preeclampsia is a form of high blood pressure (BP) in pregnancy. It is one of the leading causes of mortality and morbidity among pregnant women. As stated by the WHO, World Health Report (2005) "Make Every Mother and Child Count," the major causes of maternal deaths are severe bleeding/hemorrhage (25\%), infections (13\%), unsafe abortions $(13 \%)$, eclampsia $(12 \%)$, obstructed labor $(8 \%)$, other direct causes $(8 \%)$, and indirect causes $(20 \%)$.

Pregnancy-induced hypertension occurs in about 5-8\% of all pregnancies. Although the cause of PIH is unknown, certain factors are known to increase the risk of PIH, such risk factors include that PIH mostly affects young women with a first pregnancy, pregnant women younger than 20 years and those older than 40 years, women with multiple fetuses, pregnant diabetics, pregnant women with preexisting hypertension or previous episodes of preeclampsia or PIH and pregnant women with preexisting renal disease. ${ }^{[1]}$

\section{Problem burden of pregnancy-induced hypertension}

- Major cause of maternal and perinatal morbidity and mortality

- Complicates $7-10 \%$ of pregnancies:

- $70 \%$ Preeclampsia-eclampsia

- $30 \%$ chronic hypertension

- Eclampsia 0.05\% incidence

- $\quad$ Second leading cause of maternal mortality in the developed world. 
- $\quad \sim 1 / 3$ of all maternal deaths are from HTN'sive disorders

- Young female 3-fold increased risk

- In developed countries, $16 \%$ of maternal deaths due to hypertensive disorders

- Preeclampsia - a multifactorial, multi-system hypertensive disorder of pregnancy, is most dangerous

- Etiology remains unknown.

\section{Symptoms and associated risk of developing pregnancy-induced hypertension ${ }^{[2]}$}

\begin{tabular}{|c|c|}
\hline Symptoms of PIH & Risk of developing PIH \\
\hline Increased blood pressure & Is under age 20 or over age 35 \\
\hline Protein in the urine & Has a history of chronic hypertension \\
\hline Edema (swelling) & Has a previous history of PIH \\
\hline Sudden weight gain & $\begin{array}{l}\text { Has a female relative with a history } \\
\text { of PIH }\end{array}$ \\
\hline $\begin{array}{l}\text { Visual changes such as } \\
\text { blurred or double vision }\end{array}$ & Is underweight or overweight \\
\hline Nausea, vomiting & $\begin{array}{l}\text { Has diabetes before becoming } \\
\text { pregnant }\end{array}$ \\
\hline $\begin{array}{l}\text { Right-sided upper abdominal } \\
\text { pain or pain around the } \\
\text { stomach }\end{array}$ & Has an immune system disorder \\
\hline Urinating small amounts & Has kidney disease \\
\hline $\begin{array}{l}\text { Changes in liver or kidney } \\
\text { function tests }\end{array}$ & $\begin{array}{l}\text { Has a history of alcohol, drug or } \\
\text { tobacco use }\end{array}$ \\
\hline Breathing problems & Is expecting twins or triplets \\
\hline
\end{tabular}

$\mathrm{PIH}=$ Pregnancy induced hypertension

\section{Classification of hypertension in pregnancy}

\section{Chronic hypertension}

- $\quad \mathrm{BP} \geq 140 \mathrm{mmHg}$ systolic or $90 \mathrm{mmHg}$ diastolic prior to pregnancy or before 20 weeks gestation

- $\quad$ Persists $>12$ weeks postpartum.

\section{Gestational hypertension}

- High BP that develops after week 20 in pregnancy and goes away after delivery.

\section{Preeclampsia}

- Both chronic hypertension and gestational hypertension can lead to this severe condition after week 20 of pregnancy. Symptoms include high BP and protein in the urine and can lead to serious complications for both mom and baby if not treated quickly. ${ }^{[3]}$

\section{High risk of developing preeclampsia}

- First pregnancy.

- Preeclampsia or eclampsia in any previous pregnancy.

- 10 years or more since the last baby.

- $\quad$ Age 40 years or more.

- Family history of preeclampsia (in mother or sister).

- Certain underlying medical conditions:

- Preexisting hypertension.

- Preexisting renal disease.

- $\quad$ Preexisting diabetes..$^{[4]}$

\section{How can prevent gestational hypertension}

- Use salt as needed for taste

- Drink at least eight glasses of water a day

- Increase the amount of protein you take in and decrease the amount of fried foods and junk food you eat

- Exercise regularly and get enough rest

- Elevate your feet several times during the day

- Avoid drinking alcohol and beverages containing caffeine

- Your doctor may suggest you take prescribed medicine and additional supplements.

\section{Degree of hypertension}

\begin{tabular}{lccc}
\hline \multicolumn{4}{c}{ JNC 7 blood pressure classification } \\
\hline Category & Systolic & & Diastolic \\
\hline Normal & $<120$ & and & $<80$ \\
Prehypertension & $120-139$ & or & $80-89$ \\
Hypertension, stage 1 & $140-159$ & or & $90-99$ \\
Hypertension, stage 2 & $\geq 160$ & or & $\geq 100$ \\
\hline $\begin{array}{l}\text { National Heart, Lung and Blood Institute. JNC 7 Express. The Seventh Report of the } \\
\text { Joint National Committee on the Prevention, Detection, Evaluation, and Treatment } \\
\text { of High Blood Pressure, 2003 }\end{array}$
\end{tabular}

\section{Objective of the study}

- To assess self-care knowledge among pregnant women regarding hypertension.

- To know the preventive measures taken by pregnant women to check the hypertension.

- To examine the relationship between self-care knowledge and preventive measures taken with stages of hypertension among pregnant women.

\section{MATERIALS AND METHODS}

\section{Research design}

This is a cross-sectional study carried out on the knowledge, attitude, and preventive practices of PIH on women who attended antenatal clinic, Sir Sundar Lal Hospital, Banaras Hindu University, Varanasi.

\section{Research setting}

The setting of the study is the Sir Sundar Lal Hospital, Banaras Hindu University, Varanasi. It was founded in 1926.

\section{Research population}

The target population includes all pregnant women between the age group of 15-49 years, who attended antenatal clinic in the month of September to October, 2013 on every Monday in Gynae O.P.D., of Sir Sundar Lal Hospital, Banaras Hindu University, Varanasi. Total sample size includes 82 women, when the study was done.

\section{Collection of data}

A semi-structured interview schedules containing precoded questions were used for data collection. Verbal consent was taken 
by respondents and assured them for anonymity and confidentiality to ensure honest response.

\section{Analysis of data}

Data were analyzed using the Epi $\operatorname{Info}^{\mathrm{TM}} 7$ (Centers for Disease Control and Prevention (CDC), Atlanta, Georgia USA). It consisted of descriptive statistics including calculation of the frequencies, mean scores for the items.

\section{RESULT AND DISCUSSION}

Table 1 shows that more than half of the women $(\approx 63 \%)$ belong to rural areas, who attended antenatal clinic, at Sir Sundar Lal Hospital.

Table 2 shows that more than half of the women (64.63\%) belong to the age group of $18-27$ years while others $(\approx 35 \%)$ from the age group of 28-36 years.

Table 3 shows that Epigastric Pain is the most common problem among pregnant women (more than half the women $\approx 54 \%$ having the problem of Epigastric Pain), while Headache is secondary cause among pregnant women who attended antenatal clinic, at Sir Sundar Lal Hospital.

\begin{tabular}{|c|c|c|c|}
\hline Residence & Frequency & Percentage & $\begin{array}{c}95 \% \text { confidence } \\
\text { interval limits }\end{array}$ \\
\hline Rural & 52 & 63.41 & $52.05-73.78$ \\
\hline Urban & 30 & 36.59 & $26.22-47.95$ \\
\hline Total & 82 & 100.00 & - \\
\hline
\end{tabular}

\begin{tabular}{lccc}
\multicolumn{4}{l}{ Table 2: Age-wise distribution study population } \\
\hline Age group & Frequency & Percentage & $\begin{array}{c}\text { 95\% confidence } \\
\text { interval limits }\end{array}$ \\
\hline $18-27$ & 53 & 64.63 & $53.30-74.88$ \\
$28-36$ & 29 & 35.37 & $25.12-46.70$ \\
Total & 82 & 100.00 & - \\
\hline
\end{tabular}

\begin{tabular}{|c|c|c|c|}
\hline $\begin{array}{l}\text { Problems related } \\
\text { to pregnancy }\end{array}$ & Frequency & Percentage & $\begin{array}{c}95 \% \text { confidence } \\
\text { interval limits }\end{array}$ \\
\hline Epigastric pain & 45 & 54.88 & $43.49-65.90$ \\
\hline Headache & 16 & 19.51 & $11.58-29.74$ \\
\hline Pedal edema & 14 & 17.07 & $09.66-26.98$ \\
\hline Nothing & 07 & 08.54 & $02.76-22.86$ \\
\hline Total & 82 & 100.00 & - \\
\hline
\end{tabular}

\begin{tabular}{|c|c|c|c|}
\hline $\begin{array}{l}\text { Problem of } \\
\text { eclampsia }\end{array}$ & Frequency & Percentage & $\begin{array}{l}95 \% \text { confidence } \\
\text { interval limits }\end{array}$ \\
\hline No & 70 & 85.37 & $77.00-93.02$ \\
\hline Yes & 12 & 14.63 & $06.98-23.00$ \\
\hline Total & 82 & 100.00 & - \\
\hline
\end{tabular}

Table 4 shows that the overall incidence of Eclampsia is $14.63 \%$ in study population regarding PIH. A study done by Vidyadhar B Bangal, Purushottam A. Giri, Aditi S. Mahajan entitled as Maternal and Foetal Outcome in PIH: A Study from Rural Tertiary Care Teaching Hospital in India, found that the overall incidence of PIH was $8.96 \%$, which includes preeclampsia in $7.26 \%$ and eclampsia in $1.70 \%{ }^{[5]}$

Table 5 shows that on the basis of systolic blood pressure, $>1 / 4^{\text {th }}$ population are diagnosed with prehypertension whereas on the basis of diastolic blood pressure, $25.97 \%$ of the study population are diagnosed with stage of prehypertension remaining are come under the normal category.

Table 6 shows that $36.59 \%$ women are unaware about the cause of high BP whereas $31.71 \%$ women says that lack of exercise is measure cause of high BP.

According to Table 7, 62.20\% women are agreed with that they are taking low salt diet whiles other are taking normal as well as high salt diet.

Table 8 shows that more than half of the women are doing regular exercise while other are not doing any exercise.

\begin{tabular}{|c|c|c|c|c|c|c|}
\hline \multirow[t]{2}{*}{$\begin{array}{l}\text { Stage of } \\
\text { hypertension }\end{array}$} & \multicolumn{2}{|c|}{ Frequency } & \multicolumn{2}{|c|}{ Percentage } & \multicolumn{2}{|c|}{$\begin{array}{l}95 \% \text { confidence } \\
\text { interval limits }\end{array}$} \\
\hline & SBP & DBP & SBP & $\overline{\text { DBP }}$ & SBP & DBP \\
\hline Normal & 59 & 57 & 71.95 & 74.03 & $60.94-81.32$ & $62.77-83.36$ \\
\hline Prehypertension & 23 & 20 & 28.05 & 25.97 & $18.68-39.06$ & $16.64-37.23$ \\
\hline Total & 82 & 82 & 100.00 & 100.00 & - & - \\
\hline
\end{tabular}

$\mathrm{SBP}=$ Systolic blood pressure, $\mathrm{DBP}=$ Diastolic blood pressure

\begin{tabular}{lccc}
$\begin{array}{l}\text { Table 6: Reason behind high BP } \\
\begin{array}{l}\text { Reason behind } \\
\text { high BP }\end{array}\end{array}$ & Frequency & Percentage & $\begin{array}{c}\text { 95\% confidence } \\
\text { interval limits }\end{array}$ \\
\hline Don't know & 30 & 36.59 & $26.22-47.95$ \\
Lack of exercise & 26 & 31.71 & $21.87-42.92$ \\
High salt diet & 13 & 15.85 & $08.72-25.58$ \\
Stressful life & 13 & 15.85 & $08.72-25.58$ \\
Total & 82 & 100.00 & - \\
\hline
\end{tabular}

$\mathrm{BP}=$ Blood pressure

\begin{tabular}{lccc}
\multicolumn{3}{l}{ Table 7: Low salt diet among pregnant women } \\
\hline Low salt diet & Frequency & Percentage & $\begin{array}{c}\text { 95\% confidence } \\
\text { interval limits }\end{array}$ \\
\hline Yes & 51 & 62.20 & $50.81-72.68$ \\
No & 31 & 37.80 & $27.32-49.19$ \\
Total & 82 & 100.00 & - \\
\hline
\end{tabular}

\begin{tabular}{lccc}
\multicolumn{4}{l}{ Table 8: Exercise among pregnant women } \\
\hline Exercise & Frequency & Percentage & $\begin{array}{c}\text { 95\% confidence } \\
\text { interval limits }\end{array}$ \\
\hline Yes & 42 & 51.22 & $39.92-62.42$ \\
No & 40 & 48.78 & $37.58-60.08$ \\
Total & 82 & 100.00 & - \\
\hline
\end{tabular}




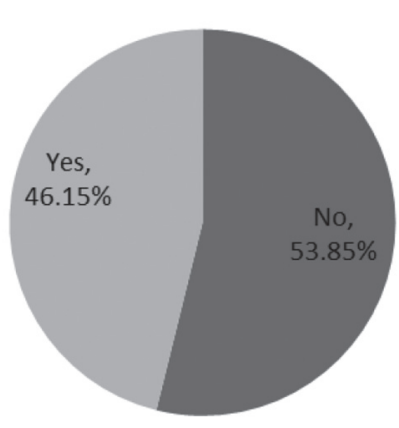

Selection

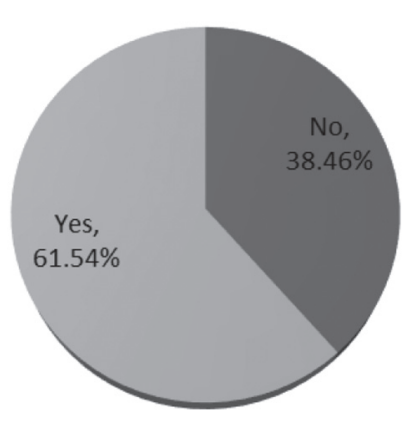

Selection
Reason behind high blood pressure $=$

"Lack of exercise"

Total agreed population $=26$

And actual number of

followers

Yes -12 and No -14

Figure 1: Association between knowledge and practices regarding high blood pressure

\section{Association between knowledge and practice}

Figure 1 shows that there is a vast gap between self-care knowledge and preventive practices among pregnant women. Less than $50 \%$ women are doing exercise during pregnancy while they all know that lack of exercise is a cause of high BP. Only $61.54 \%$ women are taking low salt diet among all women who agreed that high salt diet is major cause of high BP.

\section{CONCLUSIONS}

Pregnancy-induced hypertension is a common medical disorder seen associated with pregnancy, and it leads more complication when it unregistered. Maternal and fetal morbidity and mortality can be reduced by early recognition and institutional management.

\section{Considering the findings obtained in the study}

- To prevent PIH, there must be check BP at regular interval and

- Not only educate the Pregnant Women on the symptoms of PIH but also motivate them take preventive measures as a requirement.

\section{REFERENCES}

1. Pswarayi I. The Relationship Between Pregnancy Induced Hypertension (PIH) Self Care Knowledge and Hypertension Control Among Pregnant Mothers Aged 18 to 49 Years in Bindura District, March, 2010.

2. Pregnancy Induced Hypertension Including Eclampsia, Obstetrics and Gynecological Emergencies, 2006. http://my.clevelandclinic.org/health/ diseases_conditions/hic_Am_I_Pregnant/hic_Premature_Labor/hic_ Pregnancy-Induced_Hypertension [Last accessed on 2014 Feb 25].

3. Lindheimer MD, Taler SJ, Cunningham FG. Hypertension in pregnancy. J Am Soc Hypertens 2008;2:484-94.

4. Available from: http://www.nhs.uk/Conditions/pregnancy-and-baby/ pages/pre-eclampsia-pregnant.aspx\#close. [Last accessed on 2014 Jan 02].

5. Bangal VB, Giri PA, Mahajan AS. Maternal and foetal outcome in pregnancy induced hypertension: A study from rural tertiary care teaching hospital in India. Int J Biomed Res 2011;2:595-9.

How to cite this article: Singh V, Srivastava M. Associated risk factors with pregnancy-induced hypertension: A hospital-based KAP study. Int J Med Public Health 2015;5:59-62.

Source of Support: Nil, Conflict of Interest: None declared. 